\title{
Wat is die Woord van God - Skrif, belydenis, prediking?
}

\author{
G C Velthuysen
}

\begin{abstract}
What is the Word of God: Holy Scripture? The preaching of the Gospel? The Confession?

This article argues that while Holy Scripture and preaching may become the Word of God, although never in an unqualified manner, the same can never apply to the Confession. The Confession is the result of theological reflections on the Word and indicative of the parameters within which the preaching should remain without, however, curtailing the prophetic freedom of the preacher in proclaiming the Word. Its function is that of rule of speech for the preaching. Preaching, on the other hand, becomes a prociamation of the Word in an unsurpassable and existentially qualifying manner. Holy Scripture, a human book in more senses than one, is at the same time the Word of God, in that it qualifies its reader existentially - confronting him with the most fundamental questions on the human state and providing the final answers to these.
\end{abstract}

\section{INLEIDING}

Voordat hierdie toegespitste vraag beantwoord word, moet daar eers duidelikheid verkry word oor wat presies bedoel word wanneer die uitdrukking: 'Woord van God', gebruik word. Dit wil tog voorkom asof die antwoord op hierdie vraag bepalend gaan wees vir die antwoord op die ander vrae. Wanneer dit byvoorbeeld só verstaan word dat 'Woord van God' net (kan) verwys na direkte uitsprake van God wat vir ons woordeliks in die Heilige Skrif oorgelewer word, is dié vraag klaar beantwoord en moet daar by voorbaat reeds gesê word dat belydenis en prediking net in soverre Woord van God kan wees as wat direkte Bybelsitate daarin ' $n$ onderdak vind.

Wanneer die begrip 'Woord van God' deur die kerk, op voetspoor van die Heilige Skrif, gebruik word, is dit aanduiding van die werklikheid dat die mens aangespreek word deur 'n woord wat nie uit homself uit nie, maar van buite af op hom afkom. Dit is erkenning van die feit dat sodanige aanspraak, wat 'n finale aanspraak is en wat die mens in sy eksistensiale aanspreek, van buite af op alle mense aankom en vir hulle tot in die grond van hulle bestaan geldig is. 
Daarmee word gesê dat hierdie aanspraak nie sommer só, vanuit die eksistensie van die mens of, nog breër, vanuit die blote feit van sy Dasein kom nie. Daarmee word juis gesê dat hierdie Woord die eksistensie in Dasein van die mens bevraagteken en in ' $n$ nuwe lig stel. Daarmee word verder gesê dat hierdie aanspraak nie die resultaat van menslike denke of verbeelding is nie, en ook nie kón wees nie, omdat dit die menslike eksistensie in sodanige nuwe lig stel as wat nie vanuit die eksistensie self af te lei of te bedink is nie.

Die gebruik van die begrip 'Woord van God' gee dus uitdrukking aan die geloof dat God praat - en verder dat hierdie woord(e) wat Hy spreek, algemeen geldende krag en gesag vir alle mense van alle tye het.

\section{HOE PRAAT GOD?}

Hoé praat God? Voordat die eintlike vraag vir ons beantwoord word, moet hierdie een ook eers nog aan die orde gestel word. Ook die antwoord hierop is bepalend vir die eintlike antwoord wat ons soek.

'In die verlede het God baiekeer en op baie maniere met ons voorvaders gepraat deur die profete' (Heb 1:1). Inderdaad kry ons vanuit die Heilige Skrif ' $n$ aanduiding van sodanige pluraliteit in die toewending van God tot die mense. Daar is getuienis van onmiddellike en direkte woordelikse spreke tot Abraham, Moses, Elia en andere. Daarnaas is daar egter ook spreke van middellike spreke deur drome, visioene, gesigte en tekens - sake wat deur die profete, gelei deur die Gees van die Here, geinterpreteer is, omdat hulle die Woord van die Here hierin verneem het.

Klassieke voorbeelde in hierdie verband is die profete Jeremia en Hosea. 'n Linnegordel wat vergaan (Jer 13) en 'n mislukte skepping op die wiel van 'n pottebakker (Jer 18) word albei tekens van die verwerping van die volk, op grond waarvan Jeremia die Godspraak laat hoor: 'So sal Ek die groot hoogmoed van Juda en Jerusalem laat vergaan' (Jer 13:9). In die geval van Hosea, word sy verhouding met sy ontugtige vrou vir die profeet 'n simbool van die verhouding tussen God en Israel - sodat hy van hieruit die Godswoord tot die volk kan rig.

Hierdie voorbeelde laat die vermoede ontstaan, en open minstens die moontlikheid daarvoor, dat dit wat deur die Skrif as onmiddellike spreke betuig word, eintlik ook maar middellike spreke was. In hierdie gevalle is dit waarskynlik dat die middel waardeur die spreke van God gedra is, net nie vermeld is nie. Wat ter sprake is, is die aanspraak wat 
in en deur die teken of visioen of wat ook al op die ontvanger van die Woord gemaak is.

God praat ook deur sy dade - sy dade in die geskiedenis - aan en ten gunste van sy volk. Hierdie is 'n bedekte spreke en is nie vanselfsprekenderwys deur almal waarneembaar nie. Ook in hierdie geval is dit die taak van die profeet om die gebeurtenis te ontleed en te interpreteer, sodat die verskuilde Woord van die Here, aan die lig kan tree.

Daar is dus in hierdie geval, net soos by die vorige, sprekers van die Woord nodig sodat die Woord hoorbaar word. Die profeet is nodig. Wanneer die spreker van die Woord stil is, is die Woord stil.

God praat veral, en op 'n finale wyse, deur Jesus Christus. Hy is die groot, die éintlike spreker van die Woord - die gróót Profeet - wat Homself èn dit wat met Hom gebeur, aandui as God se groot Dáád in die geskiedenis.

Maar ook sý Woord, en Hý as die Wóórd van God, ontmoet en ontdek ons alleen in die getuienis van mense. En dan ook nie mense wat op kille, joernalistieke wyse 'n feitlike verslag van sy woorde en dade gee en daarmee volstaan nie, maar wat, op die wyse van profete, gelei deur die Gees, interpreterend en proklamerend meedeel.

Dus lyk die volgende afleiding geregverdig: Die Woord van God het ons net in die woorde van mense. En die Woord van God kom net deur die woorde van mense. Dit wil egter nie sê dat wat die kerk die Woord van God noem, bloot maar mensewoorde is nie, maar dit wil sê dat God se Woord as mensewoord en in mensewoord tot ons kom.

Met dit gesê, kan ons vervolgens daartoe oorgaan om die eintlike vraag voor ons te probeer antwoord.

\section{IS DIE HEILIGE SKRIF DIE WOORD VAN GOD?}

Ja, maar nie ongekwalifiseerd nie. Die Heilige Skrif is immers mensewoord. Plek-plek is dit uit en uit mensewoord - soos wanneer iemand die boereraat kry om ' $n$ bietjie wyn te gebruik vir sy omgekrapte maag (1 Tim 5:23) of gevra word om 'n agtergelate reismantel saam te bring wanneer hy kom kuier ( $2 \operatorname{Tim} 4: 13)$. Maar tog, in en deur hierdie mensewoord word ons op 'n onooriretbare wyse getref deur ' $n$ woord wat ons op radikale en finale wyse aanspreek - anders gesê, wat ons eksistensiaal aanspreek: wat die aanspraak tot ons rig om finale lewensbesluite te neem en wat dit doen met onweerstaanbare gesag.

Alhoewel hierbo voorbeelde genoem is van woorde uit die Skrif wat nooit iets anders sou kon wees as bloot net mensewoorde nie, is dit 
origens ' $n$ baie gevaarlike onderneming om te probeer aantoon watter woorde in die Skrif God se woorde en watter mensewoorde is. Om dit te waag, is dit nodig dat ' $n$ buite-Bybelse beoordelingskriterium aangewend moet word, met die vanselfsprekende negatiewe gevolge daaraan verbonde.

Hoe gebeur dit dan dat ons die Woord van God in die mensewoorde verneem? Dit gebeur wanneer hierdie woorde vir mý iets begin sê, wanneer dit my in my eksistensie op 'n onoortreflike manier aanspreek en kwalifiseer sodat dit finale antwoorde op mý lewensvrae gee.

\section{IS DIE PREDIKING WOORD VAN GOD?}

Ja, maar nie ongekwalifiseerd nie. Prediking is immers mensearbeid mensewoord. Dit kan ook net daar bly vassteek. Prediking kan uit en uit mensewoord bly, indien dit nie kom tot proklamasie van die goddelike Woord nie. Uiteindelik moet die prediker kan sê: So sê die Here (vgl 1 Pet 4:11).

Maar hoe is dit moontlik? Dit word eers moontlik nadat hý deur die Woord van God aangespreek is. Hy moet eers self op onoortreflike wyse daardeur gekwalifiseer word. Hy moet self eers daardeur in beslag geneem word. Sý prediking word Woord van God, wanneer hy hierdie aanspraak proklameer, wanneer hy dus as profeet die aanspraak van die Woord vir sy hoorders verwoord.

Dus: Prediking is Woord van God wanneer dit meer is as Skriflesing, wanneer dit meer is as ' $n$ redevoering óor God en sy Woord, wanneer dit selfs meer is as ' $n$ homilie, wanneer dit ten volle die bediening van die Woord is: die proklamasie van die volle waarheid en volle raad van God oor die hele wêreld van die mens.

\section{IS DIE BELYDENIS WOORD VAN GOD?}

Rondom die oorweging van hierdie vraag raak die problematiek meer gekompliseerd as wat hierbo die geval was. Allereers moet daar duidelikheid verkry word oor die vraag na die wese en funksie van die belydenis.

Die belydenis is uiting van geloof - meer bepaald uiting van geloofsdenke. Alhoewel daar hier en daar in die Nuwe Testament sprake is van belydenisse (bv Fil 2:6-11; Kol 1:15-20; 1 Tim 3:16 en 2 Tim $11-13$ ), wat as bewys dien van die feit dat selfs die heel eerste gemeentes tot belydenisvorming oorgegaan het, kan daar nie so ver gegaan 
word as om te sê dat die Heilige Skrif die belydenis bevat nie. Die Heilige Skrif bevat die boodskap - die kerugma - waarbinne daar onteenseglik belangrike leerlyne aanwysbaar is, maar wat nie 'leer' is nie. Dit is die kerk, in sy lewensituasie, daar waar hy in ' $n$ bepaalde kultuursituasie leef en met die eise van die verkondiging gekonfronteer word, wat hom op hierdie leerlyne rig om hom aan die een kant ten opsigte van die kerugma en aan die ander kant ten opsigte van die wêreld te verantwoord. Só kom hy tot dogmavorming en belydenis.

In hierdie dogmavorming of belydenisontwikkeling gebruik die kerk nie alleen woorde en begrippe vanuit die Skrif nie. Natuurlik leun hy baie swaar aan op kernwoorde uit die kerugma, maar hy gebruik ook woorde en begrippe wat eie is aan die kultuursituasie van die oomblik. So word daar byvoorbeeld vryelik gebruik gemaak van woorde uit die filosofie. Dit is begryplik, want in die belydenis gaan dit tog nie net om die reproduksie van die Bybelse waarheid nie, maar om 'n dieper tastende deurdenking en deurgronding van die kerugma.

Hierbó is reeds gestel dat die belydenis die gevolg is van die eis van die verkondiging. Die verkondiging - en meer bepaald die prediking is die hartslag van die kerk. Meer as enigiets anders is die kerk geroep om te praat - om die Woord van God te proklameer.

Soos dit geld ten opsigte van enige spreke, geld dit ook hier dat daar bepaalde spreekreëls in ag geneem moet word. Van Ruler het dit iewers so treffend gesê: Die belydenis is die grammatika van die taal van die Gees. Om dit met ' $n$ ander beeld te sê: Dit vorm die raamwerk waarbinne die prediking sal beweeg.

Wat is die verhouding tussen die prediking en die teologie? Wanneer die teologie (meer bepaald die dogmatiek) gesien word as die sistematiese deurdenking van die kerugma ten dienste van die prediking, behoort dit duidelik te wees dat hy binne dieselfde grense moet beweeg en dat hy net teen daardie grense kan aanstoot en dit kan oorskry, vir sover as wat die prediking dit doen. En die prediking doen dit; dit kan nie anders nie, want alhoewel die belydenis uit die Skrif geput is, is die Skrif nie daarmee uitgeput nie. Daar is momente, aksente en motiewe in die Skrif (kerugma) wat nie in die belydenis verdiskonteer is nie, maar wat tog gepreek moet word wanneer die prediker die hele raad van God wil verkondig.

Daarom kan daar nooit sprake van belydenisdwang wees nie. Belydenisdwang sou ' $n$ inperking en verarming van die kerugma beteken. Daarom behoort daar ook nooit sprake daarvan te wees dat die belydenis gesien word as reël van die waarheid of, miskien nog erger, reël van 
die geloof nie. Dit is hoogstens spreekreël. Maar nou is dit so dat, soos 'n digter gebruik kan maak van digterlike vryheid en soms buite die strenge reëls van die grammatiek kan beweeg, sonder om daardie reëls op te hef, maar dit doen om iets daarmee te sê wat ander nie gesê kan word nie, die kerk in sy prediking ook gebruik kan maak van 'n profetiese vryheid, sonder om daardeur die belydenis ongeldig te maak, maar dit doen om die volle waarheid van die kerugma aan die woord te stel.

So gesien, lê prediking en belydenis hoegenaamd nie op dieselfde vlak nie. Die prediking is proklamasie van die Woord van God en die belydenis dui die reëls aan waarvolgens die proklamasie sal plaasvind. Daarom kan die belydenis nie gepreek of geproklameer word nie. Daarom kan dit ook nie die materiële bron (bou?) vir die prediking wees nie. Net die Heilige Skrif kan dit wees.

Dit is hierbo gestel dat die Heilige Skrif die woord van mense is waarin en waardeur die Woord van God ons aanspreek. Die belydenis is ook mensewoord, en dit het óók te make met die Woord van God. Maar kwalitatief op 'n heel ander manier. In die Skrif kom die Woord van God tot ons in mensewoorde - in die monde van mense wat op die wyse van profete die Woord van God verneem het en dit toe gespreek het. In die belydenis het ons te maak met gelowiges se refleksie op hierdie Woord; 'n poging om twee dinge te doen: enersyds om hierdie Woord op 'n sekere manier óor te sê en andersyds om die raamwerk te verskaf waarop 'n hele lewens- en wêreldbeskouing gebou kan word. Ons het in die belydenis dus te make met iets waarin ook ander sake as net die Woord 'n rol speel.

Vandaar dat die belydenis prinsipieel altyd veranderbaar bly en eintlik hoogstens tydelike betekenis het. Vandaar dat dit nie as Woord van God bekend kan staan nie. Dit kan ánder benaminge kry; selfs pragtige en welluidende name soos 'liriek van die liefde' (Van Ruler), 'lied van die kerk' (Van Niftrik), 'Martyrium' (Weber in navolging van von Campenhausen). Tog sal al hierdie name die klem laat bly val op die menslikheid van die belydenis. Dit is menslike geloofsverantwoording. Dit kan nie Woord van God wees nie; in ieder geval nie in dieselfde sin as wat dit ten opsigte van die Heilige Skrif en selfs ten opsigte van die prediking waar is nie. Daar is in dié verband 'n duidelike kwalitatiewe verskil. Kan dit egter tog, by geleentheid, Woord van God word? Net in soverre as wat dit die Woord dra - daardie Woord wat my finaal en eksistensiaal aanspreek. En dit is die Woord wat deur die Heilige Skrif betuig word. Hierdie Woord kan my finaal aanspreek. 
Die belydenis as sodanig kan dit nie doen nie en moet dit ook nie doen nie. Vir sover as wat hy dit tog doen, is dit net omdat hy hierdie Woord reflekteer.

\section{DIE PRIMÊRE GESAG?}

'n Laaste vraag. Waar lê die prioriteit in dit alles? Waar lê die primêre gesag? Watter is sekondêr? Dit spreek eintlik vanself. Die primêre gesag lê by die Heilige Skrif, en van daaruit by die prediking as proklamering van die Woord wat in die Heilige Skrif gehoor word.

By die belydenis kan daar net sprake wees van sekondêre gesag. Hy dank sy gesag aan die Woord wat hy op een of ander wyse reflekteer. Dit is 'n gesag wat egter nooit bokant die Woord self kan staan nie. Dit wil sê, nie bokant die Skrif nie en ook nie bokant die prediking nie! Al is dit spreekreël vir die kerk en al dui dit die parameters van die verkondiging aan. Uiteindelik kan dit die Woord nie muilband nie en kan dit nie die profetiese krag van die prediking aan bande lê nie.

\section{WAT SÊ DIE PRAKTYK?}

Wat is die situasie in die praktyk? Klaarblyklik het ons daar te make met 'n klassieke voorbeeld van 'n denksirkel. As gevolg van die primêre gesag van die Heilige Skrif, is dit juis deel van die kerklike belydenis dat die belydenis voortdurend aan die Skrif getoets moet word. Dit is dan ook presies in lyn met wat hierbo gesê is. Die feit is egter dat die Skrif benader word vanuit die belydenis wat getoets moet word! Die een wat getoets moet word, bepaal dus hoe die een wat moet toets, gelees word!

$\mathrm{Al}$ is dit hoe onbedoeld, die belydenis word langs hierdie weg ' $\mathrm{n}$ sakrosante karakter verleen. Dit beteken ' $n$ verheffing van die belydenis tot iets veel meer as wat die gereformeerde ideaal daarvan wou maak. In feite beteken dit dat die Skrif, alhoewel nie de iure nie dan tog de facto, aan die interpretasie van die belydenis onderwerp word. De facto word die spreekreël reël vir die waarheid en reël vir die geloof. Dit is die dilemma van ' $n$ kerk met ' $n$ belydenis. Sonder ' $n$ belydenis kan dit tog nie - dan bly alles té vryblywend. Mét 'n belydenis dreig die verstarring.

Is dit moontlik om hierdie dilemma te oorwin? As dit nie kan nie, as dit werklik nie kan nie, moet die Reformatoriese beginsel van die prioriteit van die Heilige Skrif as 'n mite aangedui word, en moet daar 
maar erken word dat die belydenis sentraal staan en dat die Roomse beginsel voluit vir die Reformasie geld - net met ander kleertjies aan.

Die enigste moontlike manier waarop die dilemma oorwin sou kón word, sou wees om aan die Bybelondersoeker die vryheid te gee om geheel onbevange na die Woord, soos in die Skrif betuig, te luister. Geheel onbevange beteken ongebonde deur die belydenis.

Maar is dit móóntlik? Kán die teoloog hom losmaak van sý belydenis? Sal 'n doelbewuste poging om dit te doen nie juis tot belydenisverwerping lei nie? Sal dit nie juis dan die gevolg hê dat die belydenis, nou in negatiewe sin, harder saampraat as ooit vantevore nie? Ek is nie so seker daarvan dat dit hoegenaamd moontlik is nie. Dit lyk vir my dat wanneer die teoloog ' $n$ bepaalde Bybelgedeelte bestudeer met die oog daarop om die Woord daaruit te verneem, hy die ganse teologiese tradisie waarin hy staan, sáám met hom oor daardie bladsy laat buig. Hy kan hom nie heeltemal daarvan losmaak nie.

Maar laat ons aanvaar dat dit tog, in 'n sekere mate, moontlik is. Dan lê die oorwinning van die dilemma daarin dat die teoloog eers met die belydenis in gesprek tree wanneer hy alreeds sy gevolgtrekking gemaak het. Eers dan kan die toetsing van die belydenis aan die hand van die Skrif plaasvind.

Maar in ' $n$ kerk wat ' $n$ belydenis het, en waar die belydenis funksioneer as aanduiding van die parameters waarbinne die prediking en teologie sal beweeg, kan dit nie anders as dat hierdie bevinding terselfdertyd vanuit die belydenis beoordeel en getoets sal word nie!

Dit wil dus voorkom asof die toekenning van primêre en sekondêre gesag grotendeels 'n akademiese kwessie is - 'n teoretiese saak. In werklikheid sit die kerk in die praktyk vasgevang in 'n denksirkel waaruit hy nie kan losbreek, sonder om na een of ander kant iets prys te gee, wat hy nie wil of kan, sonder om sy wese in gevaar te stel nie. 